\title{
Prolactin response in beef cows and heifers suckling one or two calves
}

\author{
M. B. Wheeler, G. B. Anderson, C. J. Munro* and G. H. Stabenfeldt* \\ Department of Animal Science and ${ }^{*}$ Department of Veterinary Reproduction, University of \\ California, Davis, California 95616, U.S.A.
}

\begin{abstract}
Summary. Blood was collected, at 5 -min intervals for $3 \mathrm{~h}$, via jugular cannulation every 14 days during the first 4 months post partum from beef cows and heifers, 4 suckling 2 calves and 4 suckling 1 calf. Calves were isolated from the dams to prevent suckling for approximately $4 \mathrm{~h}$ before and $2 \frac{1}{2} \mathrm{~h}$ during sampling to obtain baseline values for prolactin, measured by radioimmunoassay. During the last 30 min of sampling, calves were allowed to suck. Milk samples were also collected at 28-day intervals from 60 females, 30 with twins and 30 with single calves, beginning 2 weeks after calving and continuing until calves were weaned at 180 days of age. No differences were observed between dams with 1 and 2 calves for baseline plasma prolactin level or for prolactin response to the suckling stimulus by 1 or 2 calves. However, milk prolactin concentration was significantly higher $(P<0.01)$ for dams with 2 calves, probably reflecting the more frequent suckling that occurs with twins. Milk prolactin value in this study was not highly correlated with the post-partum interval to first ovulation from another study on these animals. It is concluded that prolactin is not the primary factor controlling the longer post-partum interval to first ovulation in beef cattle with twins.
\end{abstract}

\section{Introduction}

The inhibitory nature of suckling on post-partum ovarian function in cattle has been described for dairy (Saiduddin, Riesen, Tyler \& Casida, 1968; Wagner \& Oxenreider, 1971) and beef cattle (Wettemann, Turman, Wyatt \& Totusek, 1978; Radford, Nancarrow \& Mattner, 1978). It has also been reported that cows suckling twins have a longer interval to first post-partum oestrus than do cows suckling single calves (Turman, Laster, Renbarger \& Stephens, 1971; Wyatt, Gould \& Totusek, 1977; Wettemann et al., 1978).

Prolactin has been implicated in the inhibition of post-partum ovarian activity induced by suckling. This is supported by work on rats (Amenomori, Chen \& Meites, 1970), monkeys (Maneckjee, Srinath \& Moudgal, 1976) and women (Rolland, Lequin, Schellekens \& de Jong, 1975; Villalobos, Canales, Zarate, Soria \& MacGregor, 1976) in which high concentrations of prolactin in the blood during lactation have been associated with the inhibition of gonadotrophin secretion. Conversely, it has been shown that when prolactin levels were suppressed, early resumption of ovarian activity occurred in ewes (Kann \& Martinet, 1975) and women (Rolland et al., 1975; Villalobos et al., 1976). However, there has been conflicting evidence regarding the role of prolactin in the cow (Williams \& Ray, 1980).

Suckling stimuli cause an increase in prolactin concentrations (Johke, 1969; Fell et al., 1971; Karg \& Schams, 1974) while augmentation of the suckling stimulus in lactating rats (McMurtry 
\& Malven, 1974) and sows (Mulloy \& Malven, 1979) by increasing litter size results in higher prolactin levels.

The purpose of this study was to determine whether differences in plasma and milk prolactin concentrations exist between beef cows suckling one or two calves.

\section{Materials and Methods}

Plasma prolactin study. Of 8 Hereford and Hereford $\times$ Angus crossbred dams that had undergone embryo transfer surgery to induce twin pregnancy, 4 had 2 calves and the rest singletons. The details of the embryo transfer procedure are described elsewhere (Anderson, Cupps \& Drost, 1979).

During the last third of pregnancy the females were fed ad libitum a ration of chopped oat hay and alfalfa hay $(1: 1)$ supplemented with phosphorus and trace minerals. The ration during the post-partum experimental period consisted of $60 \%$ oat hay, $36.8 \%$ barley, $2.0 \%$ cottonseed meal, $0.7 \%$ oyster shell flour and $0.5 \%$ trace mineral salt. The animals had an average daily gain of $0.54 \pm 0.29 \mathrm{~kg}$ during the first 45 days post partum on this ration.

During the last 35 days before parturition each female was haltered, restrained in a box stall $(1.5 \times 2.4 \mathrm{~m})$ and handled daily. Animals were familiarized to the experimental conditions well in advance of the sampling period since stress has been shown to lead to prolactin release (Tucker, 1971; Raud, Kiddy \& O'Dell, 1971).

Beginning at 30 days post partum, and every 14 days thereafter until approximately 120 days post partum, each female was fitted with an indwelling jugular cannula and bled for plasma prolactin determinations. The cannula was introduced into the jugular vein $6 \mathrm{~h}$ before sampling and maintained by flushing with sterile heparinized (1.5\%) saline $(9 \mathrm{~g} \mathrm{NaCl} / 1)$ after each blood sample was withdrawn. Blood was collected into heparinized $12-\mathrm{ml}$ tubes at 5 -min intervals during each 3-h sampling period. Animals were not aware of the exact time of sampling as the collection area was shielded from the view of the cow. Calves were separated from their dams for $2 \frac{1}{2} \mathrm{~h}$ of the sampling period but were introduced and allowed to suck for the last $30 \mathrm{~min}$. After collection, plasma was immediately obtained by centrifugation at $1000 \mathrm{~g}$, placed in ice and then kept frozen at $-15^{\circ} \mathrm{C}$ until assayed.

Milk prolactin study. Animals with twin calves (17 cows and 13 first-calf heifers) or single calves (15 cows and 15 first-calf heifers) were milked by hand at 28 -day intervals, starting at approximately 14 days post partum and continuing until weaning at 180 days. Milk samples were collected between 07:00 and 09:00 h, a time by which calves were assumed to have nursed. The milk samples were collected into 12-ml tubes, capped and placed in ice until frozen at $-15^{\circ} \mathrm{C}$.

Radioimmunoassay of prolactin. Plasma and milk prolactin concentrations were measured by the modification described by Munro, McNatty \& Renshaw (1980) of the ovine-ovine radioimmunoassay of McNeilly (1970). Bovine prolactin, NIH-P-B5 (NIAMDD, Bethesda, Maryland), was used as the reference standard and ovine prolactin, LER-860-2 (Dr L. E. Reichert, Emory University, Atlanta, Georgia), was iodinated for use as a tracer. Rabbit antiserum to ovine prolactin (NIH-P-S6) was kindly supplied by Dr J. R. McNeilly, University of Nottingham, England; this antiserum has been shown to cross-react $100 \%$ with bovine prolactin (Lamming, Moseley \& McNeilly, 1974).

Radioimmunoassay for the measurement of prolactin in milk was investigated by the determination of parallelism of inhibition curves obtained by measuring various amounts of standard prolactin (ng) or milk samples from 3 different cows $(\mu \mathrm{l})$. Triplicates were averaged to obtain a mean percentage bound for each standard or milk dilution. The inhibition curves were linearized by logit log transformation. The slopes of the transformed milk dilution inhibition curves were curved with the standards. The slopes of the milk and standard inhibition curves were similar as determined by Student's $t$ test $(P>0.05)$. 
Plasma and milk samples were stored at $-15^{\circ} \mathrm{C}$. Milk samples were heated to $40^{\circ} \mathrm{C}$ in a constant temperature waterbath and then vortexed $5 \mathrm{sec}$ before aliquots were taken for assay; 10 $\mu \mathrm{l}$ volumes were assayed in triplicate for all samples. The sensitivity of the assay was $0.2 \mathrm{ng}$ standard bovine prolactin (NIH-B-P5) per assay tube. The intra- and inter-assay coefficients of variation were $3.9 \%$ and $16.5 \%$, respectively.

Analysis of data. Baseline prolactin levels (Samples 1-27) were compared within and between individual animals across time by a one-way classification model for least squares analysis of variance for unequal subclasses (Searle, 1971). Composite baselines for each animal over time (days post partum) and for each treatment ( 1 or 2 calves) independent of time (days post partum) were compared by a one-way classification model for least squares analysis of variance for unequal subclasses. Composite plasma prolactin response curves (Samples 28-36) for each treatment ( 1 or 2 calves) independent of time (days post partum) were analysed by Student's $t$ test (Steel \& Torrie, 1960). Milk prolactin values for females suckling 1 or 2 calves were analysed by a one-way classification model for least squares analysis of variance for unequal subclasses (Searle, 1971).

\section{Results}

Text-figure 1 illustrates the plasma prolactin curves obtained during each of the six sampling periods of a representative animal suckling 1 calf, and shows that (1) after a short lead-in period involving the initiation of sampling, baseline values remained constant both within and between time periods and (2) the response to suckling remained relatively constant over the post-partum period. As the post-partum period increased, a small peak, starting at approximately Sample 27, became more obvious.

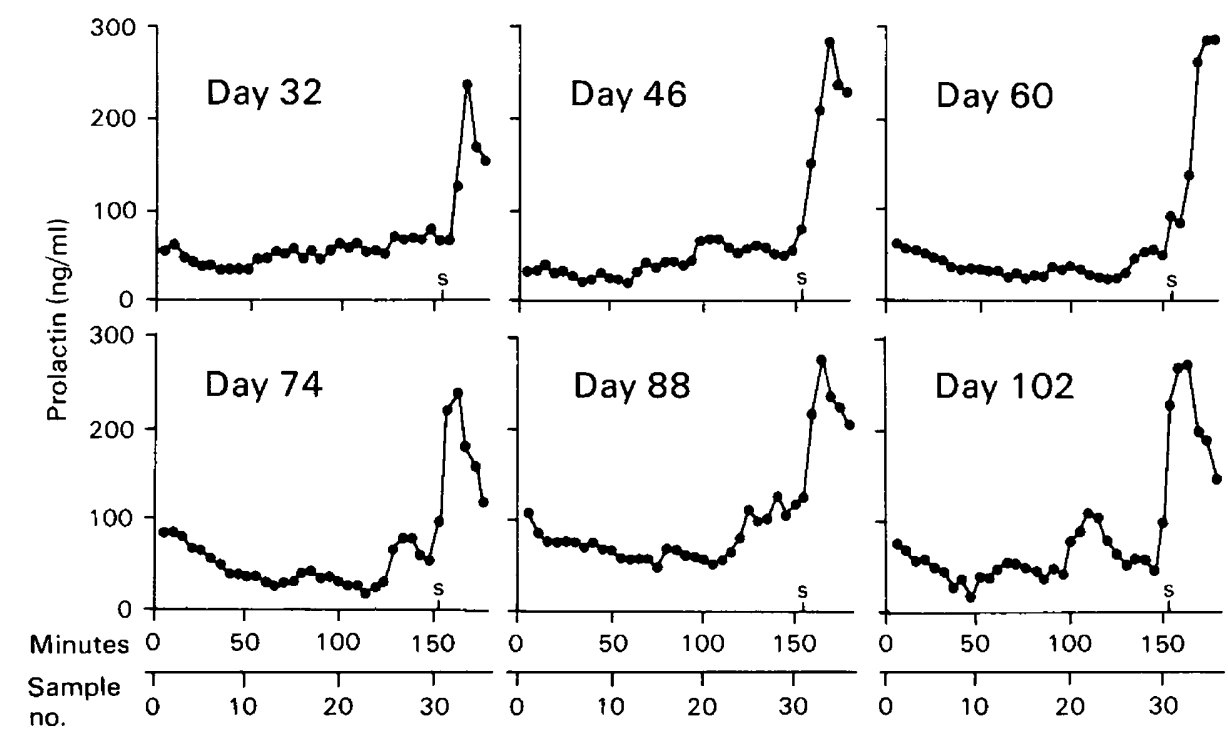

Text-fig. 1. Plasma prolactin concentrations for a representative cow suckling 1 calf obtained at 14-day intervals during lactation. S denotes the initiation of suckling.

Plasma prolactin baselines were not significantly different between individuals (Text-fig. 2) or between treatments ( 1 or 2 calves): mean \pm s.e.m. baseline values were $37.7 \pm 4.5$ and $37.7 \pm 4.3 \mathrm{ng} / \mathrm{ml}$ for animals suckling 1 or 2 calves, respectively. When curves for plasma prolactin response to suckling (Text-fig. 3) were compared for treatment groups ( 1 or 2 calves), 


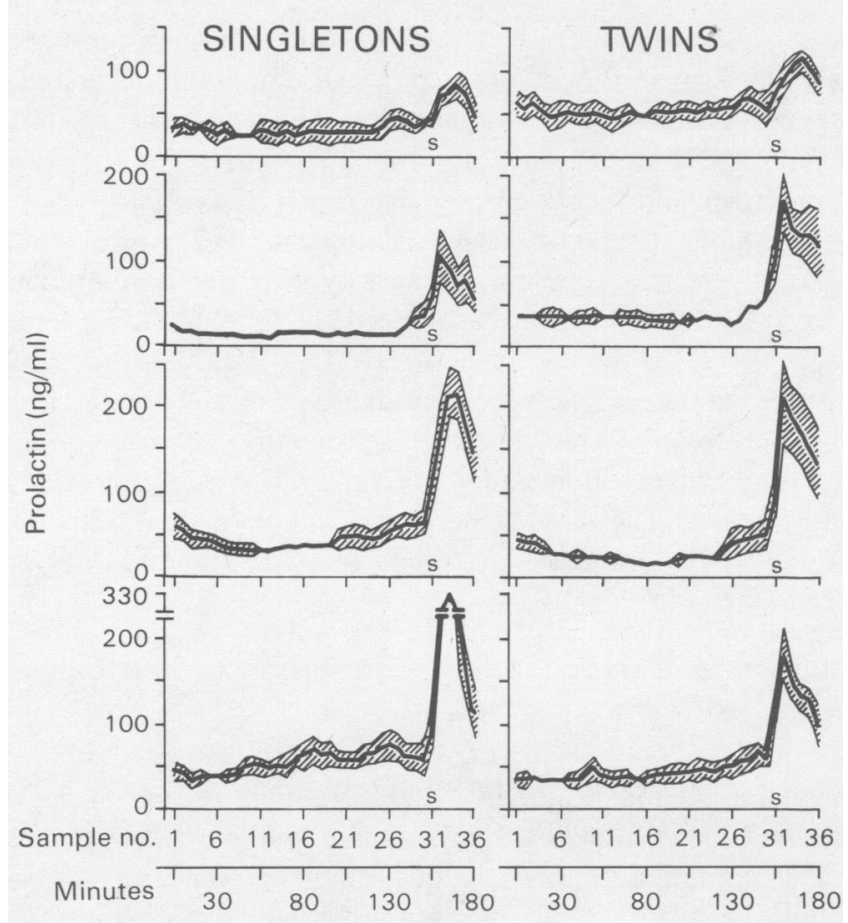

Text-fig. 2. Composite plasma prolactin concentrations in cows and heifers suckling 1 or 2 calves constructed by calculating means for each sample (standardized as samples before and after suckling) over the 6 or 7 sampling periods for each dam. S denotes the initiation of suckling and is standardized to Sample 31. Standard errors plotted are those values larger than $5 \mathrm{ng} / \mathrm{ml}$.

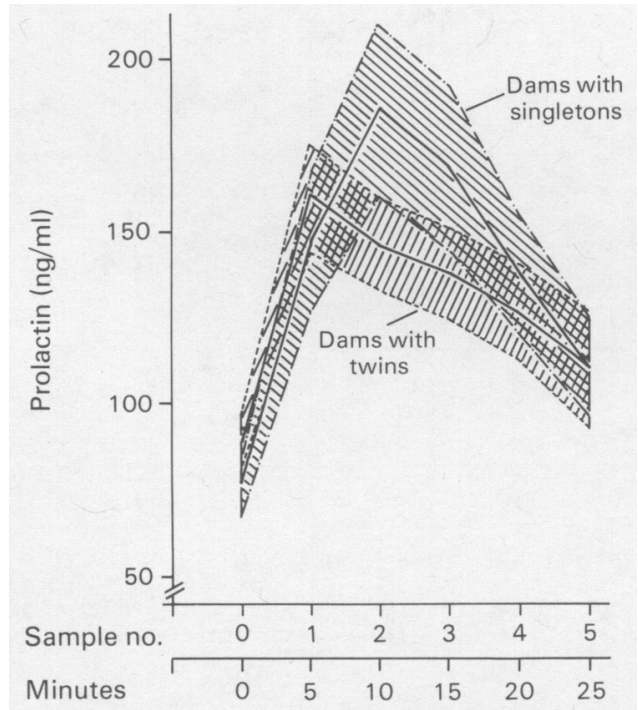

Text-fig. 3. Composite curves for the plasma prolactin response to suckling for cows and heifers with 1 or 2 calves. Curves are the composites of the response to suckling across time (post-partum period) in individual animals with Sample 0 standardized as the first sample taken after suckling was initiated. Hatched areas represent s.e.m. 
Table 1. Confidence intervals $(95 \%)$ for plasma prolactin levels $(\mathrm{ng} / \mathrm{ml})$ in cows and heifers with 1 or 2 calves during suckling

\begin{tabular}{crr}
\hline Sample no. & \multicolumn{1}{c}{ Singletons } & \multicolumn{1}{c}{ Twins } \\
\hline 0 & $55 \cdot 2-95 \cdot 6$ & $73 \cdot 1-105 \cdot 9$ \\
1 & $109 \cdot 5-182 \cdot 5$ & $126 \cdot 7-193 \cdot 3$ \\
2 & $133 \cdot 5-236 \cdot 5$ & $117 \cdot 7-174 \cdot 3$ \\
3 & $119 \cdot 5-218 \cdot 5$ & $109 \cdot 7-166 \cdot 3$ \\
4 & $102 \cdot 4-173 \cdot 6$ & $98 \cdot 8-155 \cdot 2$ \\
5 & $79 \cdot 3-142 \cdot 7$ & $73 \cdot 5-146 \cdot 5$ \\
\hline
\end{tabular}

Sample 0 was the first blood sample collected after the calf or calves initiated suckling and may or may not correspond to first sample after calves were re-introduced to cows and given the opportunity to suck. Samples were collected at 5-min intervals.

no significant differences were observed. This is further illustrated in Table 1 which shows an overlap of the $95 \%$ confidence intervals for the two treatments for each sample that followed the suckling stimulus.

Milk prolactin levels (Table 2) in cows and heifers that suckled twins were significantly greater $(P<0.01)$ than for cows and heifers that suckled single calves. The combined values were also significantly different $(P<0.01)$.

Table 2. Milk prolactin concentrations $(\mathrm{ng} / \mathrm{ml})$ for cows and heifers suckling 1 or 2 calves

\begin{tabular}{cccc}
\hline No. of calves & Cows & Heifers & Total \\
\hline 1 & $279 \cdot 5 \pm 17 \cdot 1(95)^{\mathrm{a}}$ & $238 \cdot 2 \pm 13 \cdot 1(92)^{\mathrm{b}}$ & $259 \cdot 2 \pm 10 \cdot 9(187)^{\mathrm{c}}$ \\
2 & $346.9 \pm 19 \cdot 2(105)^{\mathrm{a}}$ & $315 \cdot 7 \pm 21.5(73)^{\mathrm{b}}$ & $334 \cdot 1 \pm 14 \cdot 3(178)^{\mathrm{c}}$ \\
\hline
\end{tabular}

Values are mean \pm s.e.m. for the no. of observations in parentheses. Values with the same superscript letter are significantly different at $P<0.01$.

\section{Discussion}

The maintenance of relatively constant plasma prolactin baseline levels over the stage of lactation observed in this study is in agreement with the data of Koprowski \& Tucker (1973) who showed similar pre-milking (baseline) serum prolactin levels in lactating Holsteins until between 12 and 16 weeks of lactation. Acclimatization of the animals to the experimental conditions to avoid the effects of stress on prolactin secretion (Tucker, 1971; Raud et al., 1971) was successful, as shown by the flat baseline in Text-fig. 1. The slight evaluation in plasma prolactin at the beginning of the sampling regimen is probably due to initial excitement of the animals.

The sharp rise in plasma prolactin in response to suckling within animals was very similar with regard to the peak level attained. In some animals, there was a slight rise in plasma prolactin levels beginning at approximately Sample 27 (15 min before entry of the calf) which appeared to be more pronounced as lactation proceeded. This rise in plasma prolactin probably occurred as the dams became familiar with the procedure and anticipated suckling when the calves were sorted and placed nearby before reintroduction. Johke (1969) showed that stimuli associated with milking can cause rapid increases of plasma prolactin in cows.

Baseline levels of plasma prolactin were similar in animals suckling 1 or 2 calves and similar to levels reported by Renegar, Hafs, Britt \& Carruthers (1978) for lactating dairy cattle. The plasma prolactin response to the suckling stimulus (Text-fig. 3) was also similar, although the 
peak response appeared to occur earlier for dams suckling twins and to be slightly greater for those suckling singletons. However, mean values for each sample after suckling had begun were not different for dams in the two groups. The high degree of overlap between the $95 \%$ confidence intervals (Table 1) is indicative of the similarity in the suckling-induced plasma prolactin response to 1 or 2 calves. Peak values from the baseline are in agreement with those reported to occur with suckling or milking (Fell et al., 1971; Koprowski \& Tucker, 1973).

Although there was no apparent difference in the baseline plasma prolactin levels between dams with 1 or 2 calves or in the responses of these dams at each suckling time, milk prolactin values were different. Prolactin concentrations in milk were significantly higher $(P<0.01)$ in cows and heifers that suckled twins than those suckling single calves. Milk prolactin levels have been shown to reflect plasma prolactin concentration averaged over time in sheep, goats and cattle (Malven, 1977). Behavioural studies with the animals in this experiment (Price, Thos \& Anderson, 1981) and other beef cattle (Wyatt et al., 1977) showed that dams with twins suckled more frequently and for longer periods than did dams suckling single calves.

Increased concentrations of prolactin during lactation have been associated with the inhibition of gonadotrophin secretion, which suggests that prolactin may serve a role in the delay of post-partum ovulation induced by suckling (Amenomori et al., 1970; Rolland et al., 1975; Maneckjee et al., 1976). Data obtained in conjunction with this study on the mean interval to first post-partum ovulation were not significantly different, $42.4 \pm 4.2$ and $49 \cdot 8 \pm 4 \cdot 3$ days, for dams suckling 1 or 2 calves, respectively (Wheeler, Anderson, BonDurant \& Stabenfeldt, 1981). The correlation coefficient for the interaction of the interval to first post-partum ovulation and milk prolactin concentration was significantly different from $0(r=0.31, P<0.05)$, but the correlation was small and the coefficient of determination $\left(r^{2}=0.096\right)$ very low. This supports the work by Carruthers \& Hafs (1980) which indicated prolactin did not appear to mediate directly the effects of suckling on post-partum episodic LH secretion and/or ovulation. These data also support the conclusions of Williams \& Ray (1980), and Gimenez et al. (1980) who failed to provide evidence that prolactin is antigonadotrophic in cattle.

We thank Susan Donahue, Mary Horton and Peggy Zane for contributions to this research which was supported in part by funds from the Competitive Research Grant Program, Cooperative State Research Service, USDA, and "Steroids in Domestic Animals", Agricultural Experiment Station, University of California, Davis.

\section{References}

Amenomori, Y., Chen, C.L. \& Meites, J. (1970) Serum prolactin levels in rats during different reproductive states. Endocrinology 86, 506-510.

Anderson, G.B., Cupps, P.T. \& Drost, M. (1979) Twinning in beef cattle following unilateral and bilateral embryo transfer. J. Anim. Sci. 49, 10371042.

Carruthers, T.D. \& Hafs, H.D. (1980) Suckling and four-times daily milking: influence on ovulation. estrus and serum luteinizing hormone, glucocorticoids and prolactin in postpartum Holsteins. J. Anim. Sci. 50, 919-925.

Fell, L.R., Beck, C., De B. Blockey, M.A., Brown, J.M., Catt, K.J., Cumming, I.A. \& Goding J.R. (1971) Prolactin in the dairy cow during suckling and machine milking. J. Reprod. Fert. 24, 144, Abstr.

Gimenez, T., Henricks, D.M., Ellicott, A.R., Chang, C.H., Rone, J.D. \& Grimes, L.W. (1980) Prolactin and luteinizing hormone $(\mathrm{LH})$ release throughout the postpartum period in the suckled first-calf beef cow. Theriogenology 14, 135-149.

Johke, T. (1969) Prolactin release in response to milking stimulus in the cow and goat estimated by radioimmunoassay. Endocr. Japon. 16, 179-185.

Kann, G. \& Martinet, J. (1975) Prolactin levels and duration of postpartum anoestrus in lactating ewes. Nature, Lond. 257, 63-64.

Karg, H. \& Schams, D. (1974) Prolactin release in cattle. J. Reprod. Fert. 39, 463-472.

Koprowski, J.A. \& Tucker, H.A. (1973) Serum prolactin during various physiological states and its relationship to milk production in the bovine. Endocrinology' 92, 1480-1487.

Lamming, G.E., Moseley, S.R. \& McNeilly, J.R. (1974) Prolactin release in sheep. J. Reprod. Fert. 40, $151-168$.

Malven, P.V. (1977) Prolactin and other protein hormones in milk. J. Anim. Sci. 45, 609-616. 
Maneckjee, R., Srinath, B.R. \& Moudgal, N.R. (1976) Prolactin suppresses release of luteinizing hormone during lactation in the monkey. Nature, Lond. 262, 507-508.

McMurtry, J.P. \& Malven, P.V. (1974) Radioimmunoassay of endogenous and exogenous prolactin in milk of rats. $J$. Endocr. 61, 211-217.

McNeilly, J.R. (1970) A solid phase radioimmunoassay for ovine prolactin. J. Endocr. 49, 141-149.

Mulloy, A.L. \& Malven, P.V. (1979) Relationships between concentrations of porcine prolactin in blood serum and milk of lactating sows. J. Anim. Sci. 48, $876-881$.

Munro, C.J., McNatty, K.P. \& Renshaw, L. (1980) Circa-annual rhythms of prolactin secretion in ewes and the effect of pinealectomy. $J$. Endocr. 84, 83-89.

Price, E.O., Thos, J. \& Anderson, G.B. (1981) Maternal responses of beef cattle to single versus twin calves. $J$. Anim. Sci. (In press).

Radford, H.M., Nancarrow, C.D. \& Mattner, P.E. (1978) Ovarian function in suckling and nonsuckling beef cows post partum. J. Reprod. Fert. 54, 49-56.

Raud, H.R., Kiddy, C.A. \& O'Dell, W.D. (1971) The effects of stress upon the determination of serum prolactin by radioimmunoassay. Proc. Soc. exp. Biol. Med. 136, 689-693.

Renegar, R.H., Hafs, H.D., Britt, J.H. \& Carruthers, T.D. (1978) Luteolysis, growth hormone, glucocorticoids, prolactin and milk production in lactating dairy cows given prostaglandin $\mathrm{F}_{2}$. J. Anim. Sci. 42, 532-537.

Rolland, R., Lequin, R.M., Schellekens, L.A. \& de Jong, F. H. (1975) The role of prolactin in the restoration of ovarian function during the early postpartum period in the human female. 1. A study during physiological lactation. Clin. Endocr. 4, 15-26.
Saiduddin, S., Riesen, J.W., Tyler, W.J. \& Casida, L.E. (1968) Relation of postpartum interval to pituitary gonadotropins, ovarian follicular development and fertility in dairy cows. Res. Bull. Wisc. Agr. Exp. Stn 270, 15-23.

Searle, S.R. (1971) Linear Models. Wiley, New York.

Steel, R.G.D. \& Torrie, J.H. (1960) Principles and Procedures of Statistics. McGraw-Hill, New York.

Tucker, H.A. (1971) Hormonal response to milking. $J$. Anim. Sci. 32, Suppl. 1, 137-141.

Turman, E.J., Laster, D.B., Renbarger, R.E. \& Stephens, D.F. (1971) Multiple birth in beef cows treated with equine gonadotropin (PMSG) and chorionic gonadotropin (HCG). J. Anim. Sci. 32, 962-967.

Villalobos, H., Canales, E.S., Zarate, A., Soria, J. \& MacGregor, C. (1976) Effect of prolactin suppression on gonadotropin secretion in the puerperium. Acta endocr., Copenh. 83, 236-242.

Wagner, W.C. \& Oxenreider, S.L. (1971) Endocrine physiology following parturition. J. Anim. Sci. 32, Suppl. 1, 1-16.

Wettemann, R.P., Turman, E.J., Wyatt, R.D. \& Totusek, R. (1978) Influence of suckling intensity on reproductive performance of range cows. J. Anim. Sci. 47, 342-346.

Wheeler, M.B., Anderson, G.B., BonDurant R.H. \& Stabenfeldt, G.H. (1981) Post-partum ovarian function and fertility in beef cattle that produce twins. $J$. Anim. Sci. (in press).

Williams, G.L. \& Ray, D.E. (1980) Hormonal and reproductive profiles of early postpartum beef heifers after prolactin suppression or steroid-induced luteal function. J. Anim. Sci. 50, 906-918.

Wyatt, R.D., Gould, M.B. \& Totusek, R. (1977) Effects of single vs. simulated twin rearing on cow and calf performance. J. Anim. Sci. 45, 1409-1414.

Received 21 July 1981 